\title{
A postural load' occupational risk in grape cultivation
}

\author{
SAVITA KUMARI AND MANJU MEHTA
}

Received: 06.04.2017; Revised: 28.04.2017; Accepted: 15.05.2017

See end of the paper for authors' affiliations SAVITA KUMARI

Department of Family Resource

Management, College of Home Science, C.C.S. Haryana Agricultural University, HISAR (HARYANA) INDIA

Email : jrozydhiman@gmail.com
DABSTRACT : The aim of this study was to find out a postural load occupational risk in grape cultivation. The research designs comprised on field study conducted on 15 respondents were engaged on grapes cultivation activities. Physical fitness was determined by calculating the physiological parameters i.e. blood pressure, body temperature, pulse rate and $\left(\mathrm{VO}_{2} \max \right)$. Occupational risk was assessed through Biomechanical stress viz., Grip strength, Flexi curve and RULA score. The results indicated that mean height and weight of workers involved grape activities was $159.9 \mathrm{~cm}$ and $64.2 \mathrm{~kg}$, respectively. BMI was observed as $21.8 \mathrm{~kg} / \mathrm{m}^{2}$, fat percentage was worked out to 29.9 per cent, and hence LBM was $44.1 \mathrm{~kg}$ with variation of $\pm 19.3 \mathrm{~kg}$. $\mathrm{VO}_{2}$ max was found to be $31.8 \mathrm{ml} / \mathrm{kg} \mathrm{x}$ min exhibiting that the subjects were having good health. Conclusively on the basis of biomechanical stress in the grape cultivation occupational risk was highest in land preparation (46.3) followed by pruning activity (41.8) and least was in plant protection activity (21.5).

KEY WORDS: A postural load, Occupational risk, Grape cultivation, Physical fitness

- HOW TO CITE THIS PAPER : Kumari, Savita and Mehta, Manju (2017). A postural load' occupational risk in grape cultivation. Asian J. Home Sci., 12 (1) : 226-234, DOI: 10.15740/HAS/AJHS/12.1/226-234. 